\title{
Presence of carbepenemase-producing Enterobacteriaceae in the River Lambro basin, Italy: might sediment represent an important resistance reservoir?
}

\author{
Sara Giordana Rimoldi, ${ }^{1}$ Francesca Romeri, ${ }^{1}$ Anna Gigantiello, ${ }^{1}$ Cristina Pagani, ${ }^{1}$ Luigi Viganò,${ }^{2}$ Annunziata Calvagna, ${ }^{1}$ \\ Alessandro Tamoni, ${ }^{1}$ Mafalda Maresca, ${ }^{1}$ Maria Rita Gismondo, ${ }^{1}$ Fabrizio Stefani ${ }^{2 *}$ \\ ${ }^{1}$ Laboratorio di Microbiologia Clinica, Virologia e Diagnostica delle Bioemergenze, ASST Fatebenefratelli Sacco, Milan; ${ }^{2}$ National \\ Research Council, Water Research Institute, Brugherio (MB), Italy
}

\begin{abstract}
In the last years, the rapid spread in anthropized ecosystems of pathogens which are resistant to carbapenem antibiotics has raised great concern. In this study, KPC-producing Klebsiella pneumoniae was found in the River Lambro in June 2019, whereas KPC-producing Klebsiella oxytoca and Citrobacter braakii were identified in untreated wastewaters. Susceptibility profiles indicated resistance to imipenem, ertapenem and meropenem. Different carbapenamase genes $\left(\mathrm{bla}_{\mathrm{KPC}}, \mathrm{bla}_{\mathrm{NDM}}, \mathrm{bla}_{\mathrm{VIM}}, \mathrm{bla}_{\mathrm{OXA}-48}\right)$ were also found in the River Lambro, although not associated to living bacteria. The presence of a wide set of carbapenemase genes and resistant pathogens show that river sediments could act as a reservoir of antibiotic resistance potentially threatening human health.
\end{abstract}

\section{INTRODUCTION}

In the last decade, carbepenemase-producing Enterobacteriaceae (CPE) have become globally and sadly known because of their ability to cause healthcare-associated (nosocomial) infections that are resistant to antibiotics (Bonomo et al., 2018). In addition, the fact that CPE are being identified with increasing frequency not only within healthcare facilities but also in the environment, is of great concern. Carbapenemases (e.g., KPC, IMI, SME, GES, NDM, VIM, IMP, OXA-48) can hydrolyse not only carbapenems but almost all $\beta$-lactam antibiotics. KPC, NDM, VIM and OXA-48 represent some of the most common carbapenemases, whose genetic traits are com-

Corresponding author: stefani@irsa.cnr.it

Key words: River Lambro; Carbapenemase; Enterobacteriaceae; bla $_{\mathrm{KPC}} ;$ Klebsiella.

Contributions: All the authors made a substantive intellectual contribution. All the authors have read and approved the final version of the manuscript and agreed to be accountable for all aspects of the work.

Conflict of interest: The authors declare that they have no competing interests, and all authors confirm accuracy.

Received: 4 May 2021.

Accepted: 2 July 2021.

This work is licensed under a Creative Commons Attribution NonCommercial 4.0 License (CC BY-NC 4.0).

${ }^{\circ}$ Copyright: the Author(s), 2021

Licensee PAGEPress, Italy

J. Limnol., 2021; 80(3):2029

DOI: 10.4081/jlimnol.2021.2029 monly located on plasmids, a condition which favours the transfer of resistance genes among bacterial cells. Moreover, the resistances to $\beta$-lactams, biocides and metals often coexist on the same plasmid and can be co-selected and co-transmitted, increasing the spread of multi drug resistant (MDR) bacteria.

Although the detections of carbapenemase coding genes in natural environments are increasing, their origins, transmission cycles and risks to humans are still limitedly understood (Khan et al., 2018; Proia et al., 2018). However, concern for the spread in natural environments of MDR pathogens carrying carbapenemases (Klebsiella pneumoniae (Schroeter, 1886) Trevisan, 1887, Pseudomonas aeruginosa (Schröter 1872), Migula 1900 and Acinetobacter baumanii Bouvet and Grimont 1986 in particular) is raising (Mills and Lee, 2019).

The main purpose of this study was to investigate the occurrence of a set of carbapenemase genes and related pathogen strains in sediments of the River Lambro and in untreated wastewaters pertaining the same river basin. Draining one of the most densely inhabited areas in Europe $\left(\sim 1500\right.$ inhabitants $\left./ \mathrm{km}^{2}\right)$, this river is a tributary of the main Italian watercourse, the River Po, and contributes significantly to its contamination up to the Adriatic Sea (Viganò et al., 2015). In this regard, previous studies have demonstrated several impacts on the biotic communities exposed to the contaminants transported by the River Lambro (Viganò et al., 2016).

\section{METHODS}

Using a Ponar grab sampler, a composite sediment sample $(100 \mathrm{~mL})$ was collected in the River Lambro in June, 2019, about 250 meters upstream of the confluence with the River Po (32T 542905.87 E, 4998685.70 N) (Fig. 1). The sediment sample was kept refrigerated at 
$4^{\circ} \mathrm{C}$ in sterile PPT bottles until processing. We also collected a sample of suspended solids (sample $\mathrm{Bi}, 50 \mathrm{~mL}$ ) from the raw wastewater of a treatment plant (WWTP), and a river sediment sample downstream of the same WWTP (sample Bd, $50 \mathrm{~mL}$ ) discharging into the River Lambro. Both samples were kept in sterile PPT bottles at $4^{\circ} \mathrm{C}$ and immediately transferred to the Clinical Microbiology, Virology and Bioemergency Laboratory of ASST Fatebenefratelli Sacco (Milan, Italy) for subsequent analyses.

Bacterial strains were obtained from microbiological cultures on agar plates selective for Gram positive and Gram-negative bacteria (Mannitol Salt Agar and MacConckey Agar plates, respectively) and on CARB agar to phenotypically highlight the resistance to carbapenems (Biomerieux, France). Plates were incubated overnight at $37^{\circ} \mathrm{C}$. The identification of species was obtained by Vitek MS (BioMèrieux). The susceptibility profiles were determined by Vitek2 System (BioMèrieux) according to the manufacturer protocol and interpreted according to the European Committee on Antimicrobial Susceptibility Testing (EUCAST) 2019 breakpoints.

The carbapenemase gene presence was confirmed directly from samples and from colonies growth on selected agar by Xpert Carba-R test (GeneExpert, Cepheid), in accordance with the manufacturer protocol. Before amplification, DNA was extracted by using the UltraClean microbial DNA isolation kit or the Power-Soil DNA Isolation Kit (Mo Bio Laboratories, Carlsbad, CA, USA) for the isolated strains, or for $0.25 \mathrm{~g}$ of the environmental samples respectively, according to the manufacturer protocols. The quality of DNA was assessed by agarose gel electrophoresis.

Xpert Carba- $R$ test is able to detect the $b^{2} a_{\mathrm{KPC}}, \mathrm{bla}_{\mathrm{NDM}}$, bla $_{\text {VIM }}$, bla $_{\text {OXA }}$ (variants 48, 162, 163 and 204) and bla $_{\text {IMP }}$ (variants 1, 3, 6, 10, 25 and 30) genes. The isolates were subjected to whole genome sequencing (WGS) typing. Genomic libraries were produced and sequenced using Ion Torrent Personal Genome Machine (PGM, Ion Torrent, Thermo Fisher, Italy) with a 2 by 250 paired-end run. The final assemblies were based on 96 to 237 contigs (400 $\mathrm{bps} / \mathrm{read}$ ), with N50 values comprised between 68,340 and 151,723 , thus covering $\sim 5.8 \mathrm{Mb}$ of the bacterial genome.

The in silico MLST analysis was made by comparing the whole-genome sequences against the MLST 2.0.0. and the K. pneumoniae Pub MLST database (http://bigsdb.pasteur.fr/klebsiella/klebsiella.html) in order to assign allelic numbers to all ST loci. The resistome of antimicrobial re-

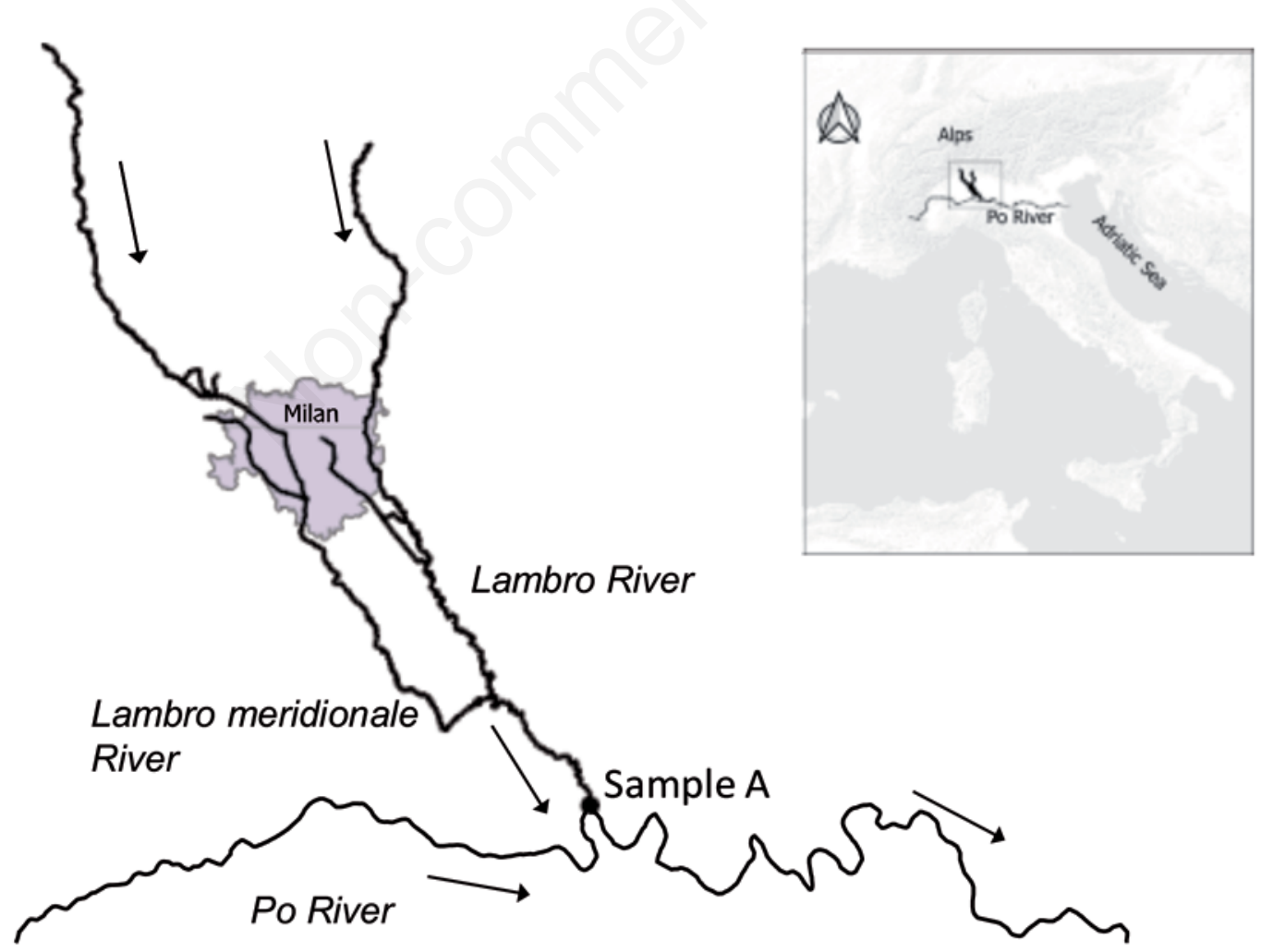

Fig. 1. Map of River Lambro and sample A location at the basin closure. The extension of the city of Milan, and the River Lambro Meridionale, which collects most of the treated wastewaters of the city, are also indicated. On the inset, the location of River Lambro in the River Po basin is shown on a wide scale. 
sistance genes was analysed using ResFinder-2.1 software (default identity thresholds [ID] 98\%) provided by the Center for Genomic Epidemiology (http://www.genomicepidemiology.org) and the resources of the Pasteur MLST $K$. pneumoniae database. PlasmidFinder-1.3 (ID 98\%; http://www.genomicepidemiology.org) was used to define the content of the plasmid replicon types. Resistance genes were considered hosted on plasmids when located on contigs identified as plasmids in the PlasmidFinder results.

\section{RESULTS AND DISCUSSION}

An MDR isolate of $K$. pneumoniae, showing a high resistance level to all carbapenems, cephalosporins, fluoroquinolones and trimethoprim-sulfametoxazole by Vitek2 System and confirmed as KPC-positive by Xpert Carba-R test (sample A, Tab. 1) was isolated from the River Lambro sediment. The carbapenem MIC values was $>8 \mathrm{mg} / \mathrm{L}$ for imipenem, $>16 \mathrm{mg} / \mathrm{L}$ for ertapenem and $>8 \mathrm{mg} / \mathrm{L}$ for meropenem. The WGS analysis indicated that this pathogen belongs to the sequence type ST-35, and that some resistance genes (including $\operatorname{dfr} \mathrm{A} 25$, tet(A) and sul1) were located on plasmid IncN. However, carbapenamase resistance genes were not associated to any plasmid, and could be harboured in other genetic mobile elements. To our knowledge, this is the first report of a KPC producing $K$. pneumoniae in the sediment of a watercourse in Italy. MDR K. pneumoniae is considered among the most worrisome resistant bacteria on a global scale, an opportunistic species and an effective source of resistance genes to other pathogens (Wyres and Holt, 2018). Only limited information is available on the diffusion of carbapenemase resistant pathogens in the Italian environment, and particularly in surface waters. In an area of the River Po basin, for example, $K$. pneumoniae carrying $\mathrm{bla}_{\mathrm{KPC}-2}$ and $\mathrm{bla}_{\mathrm{KPC}-3}$ were found in a wastewater treatment plant and in a well, but not in the associated river network (Caltagirone et al., 2017). In Central Italy, K. pneumoniae carrying bla $_{\mathrm{KPC}-3}$ was also found in WWTPs, and resulted to be related to the clinical isolate ST-512 (Perilli et al., 2013). In this context, our identification of $K$. pneumoniae bla $_{\mathrm{KPC}-2} \mathrm{ST}-35$ in Lambro sediments is even more noteworthy. In fact, although it is considered a worldwide spread variant, in Europe it has been identified only a few times and in nosocomial samples (Shen et al., 2020).

The suspended solids sample from untreated wastewater hosted MDR Citrobacter braakii Brenner et al. 1993 and Klebsiella oxytoca (Flugge 1886) Lautrop 1956 (sample Bi, Tab. 1), which grew on selective CARB agar plates. The carbapenem MIC values was $>8 \mathrm{mg} / \mathrm{L}$ for imipenem, $>16 \mathrm{mg} / \mathrm{L}$ for ertapenem and $>8 \mathrm{mg} / \mathrm{L}$ for meropenem for both the isolates from sample $\mathrm{Bi}$, and the carbapenemase gene production was confirmed as KPC-positivity by Xpert Carba-R test. P. aeruginosa was also identified in the Lambro sediment collected downstream of the WWTP discharge (sample Bd), but in this case no bla-genes were detected, and no WGS was done. The isolated $K$. oxytoca strain carried the $\mathrm{bla}_{\mathrm{KPC}-2}$ and $\mathrm{bla}_{\mathrm{OXY}-1-7}$ resistance genes, and belonged to the ST-146 strain (sample Bi, Tab. 1). This ST was originally described in Polish patients (Izdebski et al., 2018), and then in Australia (Kwong et al., 2018), but never before in Italy. Resistant genes were not harboured in any of the detected plasmids (Tab. 1), but could be hosted in other mobile elements. Resistant $K$. oxytoca was already found in two small rivers in Northern Italy, but sequence type was not determined (Caltagirone et al., 2017). The KPC-producing C. braaki (sample Bi, Tab. 1) belonged to an unknown sequence type, and the resistant bla $_{\mathrm{KPC}-2}$ gene was harboured in the plasmid IncN. However, other resistance genes, not associated with plasmids, were also found (bla ${ }_{\text {CMY-76 }}$ and aph(3')-Ia).

The genus Citrobacter is highly diverse, and many STs

Tab. 1. Antibiotic resistance genes and plasmids found in the bacteria isolated from River Lambro sediment and in suspended solids from untreated wastewaters, as indicated by whole genome sequencing. Genbank codes for genome sequencing are also reported.

\begin{tabular}{|c|c|c|c|c|c|c|c|c|c|c|}
\hline Bacteria & ST & Beta-lactam & Sulph & Tetra & Quin & Trimeth & Fosfo & Aminogl & Plasmids & Genbank \\
\hline $\begin{array}{l}\text { Klebsiella pneumoniae } \\
\text { (River Lambro, sample A) }\end{array}$ & 35 & $\begin{array}{l}\mathrm{bla}_{\mathrm{KPC}-2} \\
\mathrm{bla}_{\mathrm{SHV}-33}\end{array}$ & sul1 $^{\mathrm{a}}$ & $\operatorname{tet}(\mathrm{A})^{\mathrm{a}}$ & $\begin{array}{l}\text { oqxA } \\
\text { oqxB }\end{array}$ & dfrA25 & fosA & - & $\begin{array}{c}\operatorname{IncFIB}(\mathrm{K}) \\
\operatorname{IncFII}(\mathrm{K}) \\
\operatorname{IncN}\end{array}$ & $\begin{array}{c}\text { BioProject: } \\
\text { PRJNA736865 } \\
\text { BioSample: } \\
\text { SAMN19667786 }\end{array}$ \\
\hline $\begin{array}{l}\text { Klebsiella oxytoca } \\
\text { (Untreated WW, sample Bi) }\end{array}$ & 146 & $\begin{array}{l}\text { bla }_{\mathrm{KPC}-2} \\
\text { bla }_{\mathrm{OXY}-1-7}\end{array}$ & - & - & - & - & - & aph(3')-Ia & $\begin{array}{c}\operatorname{IncFIB}(\mathrm{K}) \\
\operatorname{IncFII}(\mathrm{K}) \\
\operatorname{IncN}\end{array}$ & $\begin{array}{c}\text { BioProject: } \\
\text { PRJNA736865 } \\
\text { BioSample: } \\
\text { SAMN19667787 }\end{array}$ \\
\hline $\begin{array}{l}\text { Citrobacter braakii } \\
\text { (Untreated WW, sample Bi) }\end{array}$ & - & $\begin{array}{l}\text { bla }_{\mathrm{KPC}-2}{ }^{\mathrm{a}} \\
\text { bla }_{\mathrm{CMY}-76}\end{array}$ & - & - & - & - & - & aph(3')-Ia & $\begin{array}{c}\text { IncHI1A(CIT) } \\
\text { IncHI1B(CIT) } \\
\text { IncN }\end{array}$ & $\begin{array}{c}\text { BioProject: } \\
\text { PRJNA736865 } \\
\text { BioSample: } \\
\text { SAMN19667788 }\end{array}$ \\
\hline
\end{tabular}


have been described internationally, and grouped into five main lineages (Liu et al., 2020). Probably, many more $C$. braaki STs exist, but they are still undescribed. Thus, it is not surprising that the ST identification of the $C$. braaki isolated in this study was not possible. ESBL genes are rarely carried by this species complex, and bla $\mathrm{KPC}-2_{2}$ positivity was signalled only for Citrobacter koseri Frederiksen, 1970. Here, interestingly, we first documented a KPC resistance associated to $C$. braaki sampled in untreated wastewater. This species is known to cause bacteremia in immune compromised patients with comorbidities, although with low virulence and incidence. Antibiotic resistance to quinolone is commonly present in Citrobacter, associated ESBL, and is often mediated by plasmids (Liu et al., 2020). Interestingly, our analysis did not find any resistance to quinolone in the isolated ST of C. braaki.

Finally, different bacteria such as Clostridium tertium (Henry 1917) Bergey et al. 1923, Bacillus megaterium de Bary 1884, Stenotrophomonas acidaminiphila Assih et al. 2002, Ochrobactrum tritici Lebuhn et al. 2000 were also found in River Lambro sediment (sample A), which are probably environmental bacteria rarely of concern for human health. No carbapenem resistance genes were detected in these bacteria. On the contrary, Xpert Carba-R test on the same sample A revealed also the presence of different genes such as bla $\mathrm{NDM}_{\mathrm{ND}}, \mathrm{bla}_{\mathrm{VIM}}, \mathrm{bla}_{\mathrm{OXA}-48}$ and $\mathrm{bla}_{\mathrm{KPC}}$ which were not associated with the bacteria isolated on selective agar plates. Previous studies showed that cultivable bacteria could represent only a small portion of the environmental microbioma, which includes a far higher number of species. Indeed, it has been estimated that only $5-10 \%$ of the total number of species assumed to be present in wastewater and wastewater treatment plants could be successfully cultivated on selective media (Kümmerer, 2004). It is therefore possible that the resistance genes that we have not found to be associated with the isolated resistant bacteria belong to microorganisms that could not grow in vitro, at least under our experimental conditions. The other hypothesis is that they are traits of dispersed gene fragments, therefore no longer associated with specific microorganisms.

\section{CONCLUSIONS}

This preliminary survey identified carbepenemaseproducing K. pneumoniae in the River Lambro sediments and other MDR Enterobacteriaceae which are potentially of concern for human health. Our findings suggest that resistant pathogens may enter surface waters directly from untreated or inefficiently treated wastewaters, as well as from combined sewer overflows (Rimoldi et al., 2020). Alternatively, the transfer of resistance genes to human pathogens mediated by mobile elements could have occurred either in wastewaters or in the receiving freshwater environments. Both the hypotheses deserve further investigations, also addressing the most likely origins of the resistance spread, and the health risk associated with its spatial range along the river network.

\section{REFERENCES}

Bonomo RA, Burd EM, Conly J, Limbago BM, Poirel L, Segre JA, Westblade LF, 2018. Carbapenemase-Producing Organisms: A Global Scourge. Clin. Infect. Dis. 66:1290-1297.

Caltagirone M, Nucleo E, Spalla M, Zara F, Novazzi F, Marchetti VM, Piazza A, Bitar I, Cicco M De, Paolucci S, Pilla G, Migliavacca R, Pagani L, 2017. Occurrence of extended spectrum $\beta$-lactamases, KPC-Type, and MCR-1.2-producing enterobacteriaceae from wells, river water, and wastewater treatment plants in Oltrepò Pavese area, Northern Italy. Front. Microbiol. 8:1-12.

Izdebski R, Baraniak A, Zabicka D, Sekowska A, GospodarekKomkowska E, Hryniewicz W, Gniadkowski M, 2018. VIM/IMP carbapenemase-producing enterobacteriaceae in Poland: Epidemic Enterobacter hormaechei and Klebsiella oxytoca lineages. J. Antimicrob. Chemother. 73:2675-2681.

Khan FA, Hellmark B, Ehricht R, Söderquist B, Jass J, 2018. Related carbapenemase-producing Klebsiella isolates detected in both a hospital and associated aquatic environment in Sweden. Eur. J. Clin. Microbiol. Infect. Dis. 37:2241-2251.

Kümmerer K, 2004. Resistance in the environment. J. Antimicrob. Chemother. 54:311-320.

Kwong JC, Lane CR, Romanes F, Silva AG da, Easton M, Cronin K, Waters MJ, Tomita T, Stevens K, Schultz MB, Baines SL, Sherry NL, Carter GP, Mu A, Sait M, Ballard SA, Seemann T, Stinear TP, Howden BP, 2018. Translating genomics into practice for real-time surveillance and response to carbapenemase-producing Enterobacteriaceae: Evidence from a complex multi-institutional KPC outbreak. PeerJ 2018;6:e4210.

Liu L, Qin L, Hao S, Lan R, Xu B, Guo Y, Jiang R, Sun H, Chen X, Lv X, Xu J, Zhao C, 2020. Lineage, antimicrobial resistance and virulence of Citrobacter spp. Pathogens 9:1-21.

Mills MC, Lee J, 2019. The threat of carbapenem-resistant bacteria in the environment: Evidence of widespread contamination of reservoirs at a global scale. Environ. Pollut. 255:113143.

Perilli M, Bottoni C, Pontieri E, Segatore B, Celenza G, Setacci D, Bellio P, Strom R, Amicosante G, 2013. Emergence of blaKPC-3-Tn4401a in Klebsiella pneumoniae ST512 in the municipal wastewater treatment plant and in the university hospital of a town in central Italy. J. Glob. Antimicrob. Resist. 1:217-220.

Proia L, Anzil A, Borrego C, Farrè M, Llorca M, Sanchis J, Bogaerts P, Balcázar JL, Servais P, 2018. Occurrence and persistence of carbapenemases genes in hospital and wastewater treatment plants and propagation in the receiving river. J. Hazard. Mater. 358:33-43.

Rimoldi SG, Stefani F, Gigantiello A, Polesello S, Comandatore F, Mileto D, Maresca M, Longobardi C, Mancon A, Romeri F, Pagani C, Cappelli F, Roscioli C, Moja L, Gismondo MR, Salerno F, 2020. Presence and infectivity of SARS-CoV-2 virus in wastewaters and rivers. Sci. Total Environ. 744:140911.

Shen Z, Gao Q, Qin J, Liu Y, Li M, 2020. Emergence of an 
NDM-5-producing hypervirulent Klebsiella pneumoniae sequence type 35 strain with chromosomal integration of an integrative and conjugative element, ICEKp1. Antimicrob. Agents Chemother. 64:e01675-19.

Viganò L, Mascolo G, Roscioli C, 2015. Emerging and priority contaminants with endocrine active potentials in sediments and fish from the River Po (Italy). Environ. Sci. Poll. Res. 22:14050-14066.
Viganò L, Loizeau JL, Mandich A, Mascolo G, 2016. Mediumand long-term effects of estrogenic contaminants on the middle River Po fish community as reconstructed from a sediment core. Arch. Environ. Contam. Toxicol. 71: 454-472.

Wyres KL, Holt KE, 2018. Klebsiella pneumoniae as a key trafficker of drug resistance genes from environmental to clinically important bacteria. Curr. Opin. Microbiol. 45:131-139. 